\title{
PEMBENTUKAN KARAKTER; (Studi Unit Kegiatan Mahasiswa UIN Sunan Kalijaga Yogyakarta)
}

\author{
Muhammad Roihan Alhaddad \\ Sekolah Tinggi Ilmu Tarbiyah Raudhatul Ulum Sakatiga \\ Email: roihan.alhaddad@gmail.com
}

\begin{abstract}
Abstrak
Latar belakang masalah yang mendorong penelitian ini adalah realitas bahwa mahasiswa yang menjadi generasi bangsa masih cenderung melakukan kegiatan-kegiatan yang dilarang oleh agama seperti melakukan kerusakan, pakaian yang tidak sopan, dan sebagainya. Tanpa disadari, unit kegiatan mahasiswa telah membantu Universitas untuk menjadikan mahasiswa berkarakter melalui kegiatan-kegiatan yang dilakukan secara terus-menerus. Dengan alasan inilah penulis meneliti lebih jauh tentang pembentukan karakter di Unit Kegiatan Mahasiswa UIN Sunan Kalijaga Yogyakarta. Maka penelitian ini bertujuan: (1) Mengetahui pembentukan karakter di Unit Kegiatan Mahasiswa UIN Sunan Kalijaga Yogyakarta. (2) Untuk Mengetahui efektifitas pembentukan karakter di Unit Kegiatan Mahasiswa UIN Sunan Kalijaga Yogyakarta. (3) Untuk mengetahui faktor pendukung dan penghambat dalam pembentukan karakter di Unit Kegiatan Mahasiswa UIN Sunan Kalijaga Yogyakarta.

Penelitian ini termasuk dalam penelitian Kualitatif deskriptif, dengan pendekatan yang digunakan berupa pendekatan Fenomenologi. Maksudnya dalam penelitian Kualitatif, data yang dikumpulkan bukan berupa angka-angka melainkan data tersebut berasal dari hasil wawancara mendalam, observasi partisipan atau catatan lapangan, dan dokumentasi. Hasil penelitian menunjukkan bahwa strategi pembentukan karakter di Unit Kegiatan Mahasiswa UIN Sunan Kalijaga Yogyakarta meliputi strategi knowing the good, strategi loving and feeling the good, strategi action the good, keteladanan, dan taubat. Strategi di atas di integrasikan dengan program kegiatan yang telah membentuk mahasiswa mempunyai karakter religius, ikhlas, tanggungjawab, percaya diri, disiplin, kepemimpinan, kreatif, kerja keras, komunikatif, peduli sosial, dan peduli lingkungan. Setelah melakukan wawancara mendalam, observasi partisipan, dan dokumentsi di lapangan bahwa dapat disimpulkan kegiatan-kegiatan yang telah dilakasanakan oleh Unit Kegiatan Mahasiswa efektif untuk membentuk karakter mahasiswa UIN Sunan Kalijaga Yogyakarta. Sedangkan dalam membentuk karakter mahasiswa melalui Unit Kegiatan Mahasiswa pasti ada faktor yang mendukung dan menghambat proses tersebut, penulis menggunakan analisis SWOT dalam melihat kedua faktor di atas yang meliputi kekuatan, kelemahan, peluang, dan ancaman. Namun semua faktor itu tidak menghambat jika mahasiswa melakukan program kegiatan dengan konsisten dan penuh tanggunjawab.
\end{abstract}

Kata Kunci: Karakter, UKM, Strategi, Efektifitas 


\section{Pembentukan Karakter; Studi Unit Kegiatan Mahasiswa UIN Sunan Kalijaga Yogyakarta Muhammad Roihan Alhaddad}

\section{Pendahuluan}

Lembaga pendidikan tinggi atau Perguruan Tinggi merupakan salah satu faktor penunjang keberhasilan bangsa dalam berbagai hal, agar mampu bersaing dengan negara lain dan meningkatkan kesejahteraan bangsa. Selain mencetak lulusan yang intelek, Perguruan Tinggi juga harus membentuk mahasiswa yang punya karakter yang baik serta mempunyai nilai keimanan dan ketakwaan kepada Tuhan yang Maha Esa.

Sudah menjadi hal biasa terlihat di media cetak maupun elektronik bahwa banyak kaum pelajar atau generasi muda selalu terlibat pada hal-hal negatif seperti penggunaan narkoba, perampokan, sex bebas, tawuran, dll. Semua hal di atas dilakukan oleh mahasiswa yang seharusnya tidak melakukan hal tersebut. Semua itu terjadi karena beberapa faktor salah satunya adalah belum terbentuknya karakter.

Menurut Doni Koesuma, karakter ialah sifat utama yang terukir baik pikiran, sikap, perilaku yang melekat dan menyatu kuat dalam diri seseorang yang membedakannya dengan orang lain. Menurut Moenir yang dikutip oleh Doni Koesuma bahwa karakter dapat dilihat dalam dua hal pertama, sebagai sekumpulan kondisi yang telah diberikan begitu saja atau telah ada sebelumnya (given). Kedua, karakter yang bisa dipahami sebagai tingkat kekuatan seseorang individu mampu menguasai kondisi tersebut (willed). (Doni Koesuma,2010:90-91)

UIN Sunan Kalijaga Yogyakarta merupakan Perguruan Tinggi keagamaan, bertanggungjawab penuh terhadap pembentukan karakter mahasiswa. Seluruh kalangan masyarakat telah memahami bahwa agama sebagai dasar dalam pembentukan karakter seseorang. Walaupun sampai saat ini masih jarang yang mengintegrasikan antara nilai-nilai religius dan nilai-nilai karakter. Tanpa mereka sadari, Unit Kegiatan Mahasiswa merupakan salah satu pembentuk karakter mahasiswa melalui kegiatan-kegiatan positif yang dirancang selama satu tahun setiap periodenya.

Mahasiswa yang mengikuti Unit Kegiatan Mahasiswa UIN Sunan Kalijaga tidak melakukan hal-hal yang negatif seperti di atas. Hal ini dicontohkan oleh Unit Kegiatan Mahasiswa Arena yang melakukan aksi memperingati Hari Pendidikan Nasional dengan damai tanpa ada kerusuhan apapun. Sikap seperti ini yang harus ditunjukkan oleh mahasiswa yang lain walaupun mengadakan aksi atau demo tetap mendahulukan kebaikan bersama dengan tidak melakukan kerusuhan yang sering muncul di media elektronik maupun media koran.

Pernyataan yang sama juga dikatakan oleh Maksudin sebagai Wakil Rektor III Bidang Kelembagaan, bahwa mahasiswa yang ikut di Unit Kegiatan Mahasiswa tidak ada yang melakukan aksi yang anarkis karena mahasiswa tersebut lebih cenderung kepada minat dan bakat dengan pengembangan karir sehingga mahasiswa yang ikut di Unit Kegiatan Mahasiswa tidak berbuat perilaku yang anarkis. 


\section{Rumusan Masalah}

1. Bagaimana Strategi Pembentukan Karakter di Unit Kegiatan Mahasiswa UIN Sunan Kalijaga Yogyakarta?

2. Bagaimana Efektifitas Pembentukan Karakter di Unit Kegiatan Mahasiswa UIN Sunan Kalijaga Yogyakarta?

3. Apa Faktor Pendukung dan Penghambat dalam Pembentukan Karakter di Unit Kegiatan Mahasiswa UIN Sunan Kalijaga Yogyakarta?

\section{Kerangka Teori}

\section{Pengertian Pendidikan Karakter}

Karakter dalam kamus besar bahasa Indonesia adalah sifat-sifat kejiwaan, akhlak, atau budi pekerti yang membedakan seseorang dari orang lain, tabiat, watak. (Tim Bahasa Pustaka Agung Harapan,2003:300) Menurut Wynne, istilah karakter diambil dari bahasa Yunani yang berarti to mark (menandai), istilah ini lebih fokus pada tindakan atau tingkah laku. Menurutnya ada dua pengertian tentang karakter. Pertama, menunjuk pada bagian seseorang yang bertingkah laku. Apabila berperilaku tidak jujur, kejam tentu orang tersebut memanifestasikan perilaku buruk. Sebaliknya, apabila sesorang berperilaku jujur, suka menolong, tentu orang tersebut memanifestasikan karakter mulia. Kedua, istilah karakter erat kaitannya dengan personality. Seseorang baru bisa disebut orang yang berkarakter apabila tingkah lakunya sesuai dengan kaidah moral. (Ratna Megawangi, Membangun SDM Indonesia Melalui Pendidikan Holistik Berbasis Karakter, melalui website www.usm.maine.com)

\section{Nilai Karakter}

Bedasarkan kajian berbagai agama, norma sosial, peraturan atau hukum, etik akademik, dan prinsip-prinsip HAM telah teridentifikasi butir-butir nilai yang dikelompokkan menjadi lima nilai utama, yaitu nilai-nilai perilaku manusia dalam hubungannya dengan Tuhan, diri sendiri, sesama manusia, lingkungan dan kebangsaan. Berikut deskripsi nilai-nilai utama yang dimaksud:

a. Nilai karakter hubungannya dengan Tuhan, yaitu nilai yang bersifat religius.

b. Nilai karakter hubungannya dengan diri sendiri, yaitu 1) jujur, 2) bertanggungjawab, 3) bergaya hidup sehat, 4) disiplin, 5) kerja keras, 6) percaya diri, 7) berjiwa wirausaha, 8) berpikir logis, kritis, kreatif, dan inovatif, 9) mandiri, 10) ingin tahu, dan 11) cinta ilmu.

c. Nilai karakter hubungannya dengan sesama, yaitu 1) sadar hak dan kewajiban diri dan orang lain, 2) patuh pada aturan-aturan sosial, 3) menghargai karya dan prestasi orang lain, 4) santun, dan 5) demokratis.

d. Nilai karakter hubungannya dengan lingkungan, yaitu kepedulian terhadap sosial dan lingkungan serta mencegah kerusakan lingkungan alam dan sekitar.

e. Nilai karakter hubungannya dengan kebangsaan, yaitu 1) nasionalis dan 2) menghargai keberagaman. (Jamal,2011:36-40) 


\section{Pembentukan Karakter; Studi Unit Kegiatan Mahasiswa UIN Sunan Kalijaga Yogyakarta Muhammad Roihan Alhaddad}

\section{Strategi Pembentukan Karakter}

Sebagaimana diungkapkan oleh Lickona bahwa memiliki pengetahuan nilai moral tidak cukup untuk menjadi manusia berkarakter, nilai moral harus disertai dengan adanya karakter bermoral.(Thomas Lickona,2013:72) termasuk dalam karakter ini ada tiga komponen karakter yaitu pengetahuan tentang moral (moral knowing), perasaan tentang moral (moral feeling), dan perbuatan bermoral (moral action).

Menurut Maragustam, Jika karakter merupakan seratus persen turunan atau bawaan sejak lahir, maka karakter tidak bisa dibentuk. Namun, jika bawaan (hereditas) hanyalah salah satu faktor pembentuk karakter, tentu jawabannya bisa dibentuk semenjak usia dini. Untuk itu kesepuluh pilar karakter itu, dapat diajarkan secara sistematis dalam model pendidikan holistik menggunakan strategi mengetahui, mencintai, mengerjakan, keteladanan, dan taubat. Kelima rukun pendidikan karakter tersebut adalah sebuah lingkaran yang utuh yang dapat diajarkan secara berurutan atau tidak berurutan. (Maragustam,2010:120)

\section{Pengertian Efektifitas}

Dalam kamus ilmiah populer kata efektifitas mempunyai arti ketepatgunaan, hasil guna, dan menunjang tujuan. (Tim Prima Pena,2006:100) Efektifitas pada dasarnya mengacu pada sebuah keberhasilan atau pencapaian tujuan. Hidayat menjelaskan bahwa efektifitas adalah suatu ukuran yang menyatakan seberapa jauh target (kuantitas, kualitas, dan waktu) telah tercapai. Makin besar presentase target yang dicapai makin tinggi efektifitasnya. (Hidayat,1986:19)

\section{Indikator Efektifitas}

Gibson mengemukakan bahwa kriteria efektifitas atau indikator efektifitas dapat diukur melalui:

a. Produktivitas yaitu merupakan kemampuan organisasi UKM untuk memproduksi jumlah dan mutu output sesuai dengan permintaan lingkungan.

b. Kualitas yaitu suatu kondisi dinamis yang berhubungan dengan produk, jasa, manusia, proses, dan lingkungan yang memenuhi atau melebihi harapan.

c. Efisiensi yaitu merupakan perbandingan (ratio) antara output dengan input.

d. Fleksibilitas respon terhadap suatu organisasi atau perubahan-perubahan yang terjadi pada suatu organisasi yaitu Unit Kegiatan Mahasiswa UIN Sunan Kalijaga Yogyakarta.

e. Kepuasaan yaitu merupakan ukuran untuk menunjukan tingkat dimana organisasi dapat memenuhi kebutuhan masyarakat.

f. Keunggulan yaitu kemampuan bersaing dari organisasi dan anggota organisasi terhadap perubahan-perubahan yang ada.

g. Pengembangan yaitu merupakan mengukur kemampuan organisasi UKM UIN Sunan Kalijaga untuk meningkatkan kapasitasnya dalam menghadapi tuntutan masyarakat. (http://elib.unikom.ac.id/download.php?id=56888.) 


\section{Metode Penelitian}

\section{Jenis Penelitian}

Jenis penelitian yang digunakan adalah penelitian lapangan (Field Research) yaitu jenis penelitian yang berusaha menghimpun data penelitian secara langsung di lapangan. (Sarjono,2008:21) Jenis penelitian ini adalah penelitian Kualitatif, penelitian ini bertujuan untuk menerangkan fenomena sosial atau suatu peristiwa. (Lexy Moleong,2008:4)

\section{Pendekatan Penelitian}

Pendekatan yang digunakan dalam penelitian Kualitatif ini yaitu pendekatan Fenomenologi. Dengan pendekatan Fenomenologi ini, peneliti akan memperhatikan, mengamati fakta, gejala-gejala, peristiwa-peristiwa yang terjadi dan kemudian dituangkan dalam bentuk tulisan.

\section{Subyek Penelitian}

a. Pengurus Harian Unit Kegiatan Mahasiswa (UKM) Universitas Islam Negeri Sunan Kalijaga Yogyakarta.

b. Koordinator divisi-divisi Unit Kegiatan Mahasiswa (UKM) Universitas Islam Negeri Sunan Kalijaga Yogyakarta.

c. Mahasiswa yang mengikuti kegiatan Unit Kegiatan Mahasiswa (UKM) Universitas Islam Negeri Sunan Kalijaga Yogyakarta.

\section{Metode Pengumpulan Data}

a. Metode Observasi Partisipan

b. Metode Wawancara Mendalam

c. Metode Dokumentasi

\section{Metode Analisis Data}

a. Data Reduction (reduksi data).

b. Data Display (penyajian data).

a. Conclusion Drawing/Verification (simpulan dan verifikasi). Zainal,2011:172-17)

\section{Keabsahan Data}

Untuk pengecekan keabsahan data dalam penelitian ini menggunakan teknik trianggulasi. Triangulasi metode dilakukan dengan cara membandingkan informasi atau data dengan cara yang berbeda. Sebagaimana dikenal, dalam penelitian kualitatif peneliti menggunakan metode wawancara, obervasi, dan survei. Untuk memperoleh kebenaran informasi yang handal dan gambaran yang utuh mengenai informasi tertentu, peneliti bisa menggunakan metode wawancara bebas dan wawancara terstruktur. (Mudjia Rahardjo, Triangulasi dalam Penelitian Kualitatif, melelui website http://mudjiarahardjo.com) 


\section{Hasil Penelitian}

\section{Strategi Pembentukan Karakter}

Menurut Maksudin, bahwa pembentukan karakter di Unit Kegiatan Mahasiswa sangat tepat karena mahasiswa memilih kegiatannya sesuai dengan minat dan bakat mahasiswa sehingga tidak ada unsur paksaan dari luar. Sedangkan menurut Kholid Zulfa, pembentukan karakter di UKM berhasil karena pada Unit Kegiatan Mahasiswa mempunyai program kegiatan yang berkelanjutan dan dilakukan secara terus-menerus sehingga menjadi kebiasaan. Karakter itu bukan dikatakan namun ditunjukkan dari perilaku sehingga pembentukan karakter di Unit Kegiatan Mahasiswa sudah tepat dengan membentuk karakter yang berbeda-beda di setiap Unit Kegiatan Mahasiswa.

\section{Strategi Pembentukan Karakter di UKM Al-Mizan \\ a. Strategi Knowing the Good \\ 1) Pendidikan dan Latihan}

Unit Kegiatan Mahasiswa Al-Mizan dalam melakukan pendidikan dan latihan dengan melihat kemampuan mahasiswa yang meliputi divisi Shalawat, Tafsir, Kaligrafi, Tahfidz, dan Tilawah sehingga mahasiswa yang masuk dari tahap kaderisasi ke proses pendidikan dan latihan sudah mempunyai kemampuan dasar tentang kegiatan Al-mizan yang disebutkan di atas. Adapun nilai yang terbentuk dalam kegiatan ini yaitu:
a) Kerja Keras
b) Disiplin

\section{2) Kegiatan Workshop}

Kegiatan workshop telah dilakukan oleh divisi Tilawah dengan tujuan untuk menambah pengetahuan tentang membaca Al-Qur'an dengan baik dan benar dan juga menambah perbendaharaan lagu dan variasi dalam membaca Al-Qur'an. Kegiatan ini dirancang oleh divisi Tilawah sebanyak tiga kali dalam satu periode kepengurusan. Nilai karakter yang terbentuk dalam kegiatan workshop adalah sebagai berikut:

a) Rasa Ingin Tahu

b) Kerja Keras

\section{3) Bedah Tafsir dan Kajian Kontemporer}

Kegiatan bedah tafsir dan kajian kontemporer merupakan salah satu kegiatan yang dilakukan oleh divisi Tafsir untuk memperdalam pengetahuan anggota tentang ilmu Al-qur'an dan tafsirnya. Kegiatan ini dilakukan setiap minggu dengan bergantian satu sama lain, maksudnya minggu pertama bedah tafsir dan minggu kedua kajian kontemporer secara berkelanjutan.
a) Religius
b) Berpikir Logis
c) Gemar Membaca 


\section{4) Wisata Seni}

Kegiatan wisata seni yang dilaksanakan oleh divisi Kaligrafi yang diprogramkan satu kali dalam satu periode kepengurusan ini bertujuan Menjalin keakraban satu sama lain dalam divisi Kaligrafi dan ingin mendapatkan ilmu pengetahuan dari sanggar lain. Adapun karakter yang diharapkan dari kegiatan ini yaitu:
a) Rasa Ingin Tahu
b) Kreatif

\section{b. Strategi Action the Good}

Pada tahap ini, mahasiswa dilatih untuk berbuat mulia. Tanpa melakukan apa yang sudah diketahui atau dirasakan oleh seseorang, tidak akan ada artinya selama ini hanya himbauan saja, padahal berbuat sesuatu yang baik itu harus dilatih, dan menjadi bagian dari kehidupan sehari-hari. (Maragustam, 2010:120)

\section{1) Kegiatan Rutin}

a) Latihan Rutin

Latihan rutin dilakukan oleh semua divisi unit kegiatan mahasiswa JQH AlMizan dengan tujuan untuk memahami, menguasai bidang yang ditekuninya seperti divisi Tilawah melakukan latihan tiga kali dalam seminggu (selasa, kamis, sabtu), divisi Tafsir melakukan latihan jurnalistik dua kali dalam satu bulan, divisi sholawat dua kali seminggu, divisi kaligrafi tiga kali seminggu.

b) Sima'an dan Setoran Hafalan

Sima'an ialah kegiatan mendengarkan hafalan Al-Qur'an anggota dan Pengurus dengan tujuan untuk menjaga hafalan mahasiswa, kegiatan dilakukan sebanyak dua kali dalam satu bulan. Adapun setoran hafalan bertujuan untuk menambah kuantitas hafalan anggota yang dilaksanakan dua kali dalam seminggu.

c) Silaturrahmi dan Keakraban

Kegiatan silaturrahmi dilakukan oleh semua Unit Kegiatan Mahasiswa pada umumnya dan Unit Kegiatan Mahasiswa JQH Al-Mizan khususnya. Hal ini diungkapkan oleh Haidar Ali selaku ketua JQH Al-Mizan bahwa dalam mensolidkan dan mengakrabkan anggota dibutuhkan kegiatan silaturrahmi yang baik sehinga satu sama lain mempunyai rasa kekeluargaan dalam berorganisasi dengan mengedepankan kepentingan organisasi bukan kepentingan pribadi.

d) Mizanuna Berkreasi

Mizanuna berkreasi merupakan salah satu kegiatan yang dirancang oleh Pengurus Harian untuk mewadahi kreatifitas anggota dan memupuk rasa kekeluargaan dalam mizanuna. Kegiatan mizanuna berkreasi ini dilakukan tiga kali dalam setahun dengan menumbuhkan kreatifitas anggota JQH Al-Mizan tersebut.

e) Haflah Tilawah

Haflah tilawah yaitu kegiatan yang dilaksanakan oleh divisi Tilawah untuk meningkatkan bacaan Al-qur'an anggota divisi tilawah, civitas akademik maupun 


\section{Pembentukan Karakter; Studi Unit Kegiatan Mahasiswa UIN Sunan Kalijaga Yogyakarta Muhammad Roihan Alhaddad}

masyarakat umum yang mau ikut kegiatan ini dan kegiatan ini juga sebagai motivasi bagi mahasiswa untuk membaca Al-qur'an dengan lebih baik.

f) Wisuda Hafidz dan Hafidzah

Unit Kegiatan Mahasiswa JQH Al-Mizan UIN Sunan Kalijaga Yogyakarta mempunyai program kegiatan berupa wisuda hafidz dan hafidzah untuk mengapresiasi mahasiswa dalam menghafal Al-qur'an. Kegiatan wisuda hafidz dan hafidzah dilakukan satu kali dalam satu periode kepengurusan dan telah dilaksanakan pada acara malam puncak Semarak Miladiyah JQH Al-Mizan XV yang menampilkan para qori' dan wisuda tahfidz yang terdiri dari wisuda $30 \mathrm{Juz}$, lima Juz, dan Juz 30.

Adapun karakter yang terbentuk dalam kegiatan-kegiatan rutin di atas yaitu:

(1) Disiplin

(2) Kerja Keras

(3) Kreatif

(4) Percaya Diri

(5) Rasa Ingin Tahu

(6) Tanggungjawab

(7) Menghargai Prestasi

(8) Gemar Membaca

\section{2) Lomba Kaligrafi}

Lomba kaligrafi dilaksanakan pada acara Semarak Miladiyah UKM JQH AlMizan XV dengan memberikan hadiah pada juara satu, dua, dan tiga. Pembagian hadiah dilakukan pada acara malam puncak pada hari Minggu, 23 Maret 2014 jam 19.00 WIB yang bertempat di Convention Hall UIN Sunan Kalijaga. Adapun karakter yang terbentuk dari kegiatan ini yaitu:

a) Menghargai Prestasi

b) Tanggungjawab

\section{c. Strategi Keteladanan}

Keteladanan telah dilakukan oleh para Pengurus Harian maupun koordinator divisi masing-masing UKM dengan mengikuti setiap kegiatan yang dilakukan oleh masing-masing divisi maupun mengawasi kegiatan yang dilakukan dalam hal ini seperti, kegiatan pelatihan, kaderisasi, diskusi, penulisan dll. Sehingga peran ketua harus dilakukan seperti turun langsung mengikuti maupun mengawasi setiap kegiatan tersebut sehingga para anggota juga merasa diperhatikan dengan hal tersebut.

Adapun nilai-nilai karakter yang terbentuk dalam strategi keteladanan ini adalah:
a. Sopan Santun
b. Komunikatif 
P-ISSN : 2541-3686

\section{Strategi Pembentukan Karakter di UKM Mapalaska}

a. Strategi Knowing the Good.

\section{1) Ekspedisi Karimun Jawa}

Kegiatan ekspedisi karimun Jawa merupakan kegiatan mahasiswa pecinta alam dengan target awal kegiatan adalah untuk mengetahui jenis mangrove yang ada di daerah Karimun Jawa, namun selain untuk mengetahui jenis mangrove juga diisi dengan kegiatan lain yaitu: belajar cara penyelamatan penyu sekaligus melepaskan tukik penyu, kegiatan snockling, dan kegiatan Sosiologi pedesaan dengan suku Bugis yang tinggal di Karimun Jawa. Adapun karakter yang terbentuk dalam kegiatan ini yaitu:

a) Peduli Lingkungan

b) Rasa Ingin Tahu

\section{2) Diskusi Ilmiah}

Diskusi ilmiah yang dilakukan oleh Pengurus Mapalaska dengan pembicara oleh senior Mapalaska Muhammad Nur Yani dengan materi Perubahan Iklim, pengolahan Sampah, dan Isu Lingkungan di Daerah Perkotaan. Kegiatan ini bertujuan untuk memberikan pengetahuan kepada mahasiswa tentang isu-isu yang hangat seperti perubahan yang terjadi saat ini yang menjadi tema diskusi. Karakter yang terbentuk pada kegiatan ini adalah:

a) Rasa Ingin Tahu

b) Gemar Membaca

c) Komunikatif

\section{3) Pendidikan Lanjut}

Pendidikan lanjut merupakan salah satu tahapan yang harus dilalui oleh setiap anggota baru Mapalaska sebelum dilantik menjadi anggota penuh. Tahapannya antara lain lima kegiatan pendidikan lanjut yang meliputi: Panjat Tebing, Susur Goa, Rimba Gunung, Arung Jeram, dan Lingkungan Hidup, satu pendidikan spesialisasi dan Pelantikan anggota menjadi pengurus Mapalaska. Karakter yang terbentuk melalui kegiatan ini antara lain:

a) Kerja Keras

b) Disiplin

c) Tanggungjawab

\section{b. Strategi Feeling and Loving the Good}

1) Bakti Sosial

Kegiatan bakti sosial dilakukan oleh mahasiswa Mapalaska dengan kegiatan membantu Pak Bambang dalam kegiatan pembibitan di kebun sekitar rumahnya di daerah Maguwoharjo yang telah dilakukan tanggal 22 Juni 2013. Adapun karakter yang terbentuk dalam kegiatan bakti sosial yaitu:

a) Peduli Sosial 
b) Ketulusan

\section{2) Pendakian Kemerdekaan}

Pengurus mengajak mahasiswa untuk Memperingati kemerdekaan RI yang ke 68 yang diselenggarakan dengan pengibaran bendera Merah Putih di Puncak Gunung Sindoro Wonosobo Jateng dengan tujuan untuk menanamkan sikap nasionalisme. Karakter yang tebentuk dalam kegiatan ini yaitu:

a) Cinta Tanah Air.

b) Pantang Menyerah.

\section{c. Strategi Action the Good.}

1) Pengabdian pada Masyarakat Ramadhan

Kegiatan pengabdian pada masyarakat yang dilaksanakan pada bulan Ramadhan, diisi dengan kegiatan Pengajian dimana anggota Mapalaska dituntut untuk bisa menjadi pemateri baik Kultum maupun Khutbah, selain itu diisi pula dengan kegiatan pembibitan dengan warga desa, pengajian dengan anak-anak TPA, lomba-lomba, pengobatan gratis dan kegiatan yang lainnya. Adapun karakter yang terbentuk pada kegiatan ini ialah:

a) Peduli Sosial

b) Tanggungjawab

c) Ketulusan

2) Pembuatan Kompos.

Kegiatan pembuatan kompos atau penggunaan kembali bahan-bahan yang tidak terpakai semacam tandon air yang di manfaatkan untuk pembuatan pupuk kompos. Salah satu percobaan yang dilakukan oleh anggota baru Mapalaska yaitu pembuatan pupuk kompos cair dengan memanfaatkan kotoran hewan dan pembusukan buah-buahan. Adapun karakter yang terbentuk pada kegiatan ini ialah:

a) Peduli Lingkungan

b) Rasa Ingin Tahu

3) Silaturrahmi Antar Anggota

Kegiatan silaturrahmi juga dilakukan melalui kegiatan safari ramadhan. Kegiatan ini dilaksanakan dengan mendatangi rumah alumni di sekitar daerah Yogyakarta, kegiatan ini sudah menjadi tradisi bagi alumni Mapalaska untuk menyediakan santapan berbuka puasa, sekaligus menyambung tali silaturrahmi. Adapun karakter yang terbentuk pada kegiatan ini ialah:

a) Religius

4) Kegiatan Yasinan Anggota

Kegiatan keagamaan yang dilakukan oleh Unit Kegiatan Mahasiswa Mapalaska yaitu melakukan kegiatan yasinan rutin dua kali setiap bulan yang telah disepakati oleh forum komunikasi (forkom) untuk dilakasanakan. Adapun karakter yang terbentuk pada kegiatan ini ialah:

a) Religius 


\section{Strategi Pembentukan Karakter di UKM Olahraga}

a. Strategi Knowing the Good

1) Pengadaan Pelatih

Pengadaan pelatih dilakukan untuk menambah pengetahuan dalam olahraga yang meliputi pengetahuan tentang strategi, fisik, dan kemampuan yang lainnya. Pengadaan pelatih membuat para atlet unit kegiatan mahasiswa olahraga termotivasi untuk menjadi atlet yang lebih baik lagi. Adapun karakter yang terbentuk dari pengadaan pelatih yaitu:
a) Rasa Ingin Tahu
b) Disiplin

\section{b. Strategi Action the Good}

1) Latihan Rutin

Latihan rutin dilakukan oleh setiap Unit Kegiatan Mahasiswa salah satunya UKM Olahraga yang melakukan latihan rutin setiap hari sabtu pagi dilapangan sepakbola untuk divisi sepakbola sedangkan divisi lain melakukan latihan rutin dihari yang berbeda. Adapun karakter yang terbentuk dari pengadaan pelatih yaitu:
a) Kerja Keras
b) Disiplin

\section{2) Sparing Partner}

Kegiatan ini juga mempunyai banyak manfaat baik bagi tim maupun pelatih karena setiap melakukan sparing partner dengan tim lain untuk melihat kemampuan yang selama ini telah dilatih sehingga jika ada kekurangan dari pemain maupun strateginya akan dievaluasi dengan baik oleh pelatih maupun Pengurus yang terlibat. Adapun karakter yang terbentuk dari kegiatan ini ialah:
a) Kerja Keras
b) Disiplin
c) Tanggungjawab
d) Percaya Diri

\section{3) Mengikuti Turnamen}

Kegiatan ini dilakukan oleh setiap divisi di bidang olahraga dengan tujuan yang hampir sama yaitu untuk menambah pengalaman, evaluasi tim, meningkatkan motivasi dan menambah kemampuan anggota. Adapun karakter yang terbentuk dalam kegiatan ini adalah:
a) Kerja Keras
b) Disiplin
c) Kerjasama
d) Percaya Diri 


\section{4) Mengadakan Turnamen}

Kegiatan ini dilakasanan oleh setiap divisi di unit kegiatan mahasiswa olaharaga seperti turnamen sepakbola, turnamen futsal, turnamen volly, catur, dan bulutangkis. Kegiatan seperti ini banyak manfaatnya baik bagi mahasiswa maupun UIN Sunan Kalijaga. Adapun karakter yang terbentuk dalam kegiatan ini adalah:

a) Tanggungjawab

\section{c. Strategi Taubat}

Pada tahapan ini mahasiswa diajarkan kesadaran atas kesalahannya sendiri dengan melakukan hukuman tanpa adanya pakasaan. Dalam hal ini dicontohkan oleh kegiatan UKM Olahraga cabang Sepakbola yang melakukan latihan rutin setiap hari Sabtu. Jika ada anggota yang telat datang dilapangan sepakbola maka secara langsung dia akan menghukum dirinya sendiri secara sadar dengan keliling lapangan. Kesadaran atas kesalahan ini sangat penting dilatih dan dibiasakan oleh mahasiswa untuk menjadi manusia yang selalu introspeksi dan refleksi diri.

\section{Strategi Pembentukan Karakter UKM Resimen Mahasiswa \\ a. Strategi Knowing the Good \\ 1) Pendidikan dan Latihan}

Unit Kegiatan Mahasiswa Resimen Mahasiswa (Menwa), menyerahkan kepada RINDAM IV Diponegoro Malang dalam melakukan pendidikan dan pelatihan dasar kepada anggota baru selama dua pekan. Dalam proses ini pihak Pengurus tidak ikut campur dengan proses ini karena semua pembentukan karakter mahasiswa dilakukan oleh para anggota TNI di RINDAM IV Diponegoro Malang. Karakter yang terbentuk dengan kegiatan ini yaitu:
a) Disiplin
b) Kerja Keras
c) Tanggungjawab

\section{b. Strategi Feeling and Loving the Good \\ 1) Bakti Sosial}

Salah satu kegiatan yang dilakukan adalah dengan membantu masyarakat yang membutuhkan ketika mendapat musibah atau bencana alam yang sering terjadi di Yogyakarta maupun luar Yogyakarta. Kegiatan bakti sosial ini akan membentuk karakter mahasiswa yaitu:

a) Peduli Sosial

b) Tanggungjawab

\section{2) Upacara Hari Kemerdekaan RI}

Kegiatan ini juga dilaksanakan oleh Unit Kegiatan Mahasiswa MENWA dalam mengikuti kegiatan upacara hari kemerdekaan untuk menumbuhkan sikap nasionalisme anggota dan berpartisipasi dalam kegiatannya. Kegiatan ini telah membentuk mahasiswa mempunyai karakter yaitu: 
Volume 2 Nomor 1 Edisi Juni 2017

P-ISSN : 2541-3686

a) Cinta Tanah Air

\section{c. Strategi Action the Good}

1) Latihan Search and Rescue

Latihan Search and Rescue (SAR) merupakan kegiatan kemanusiaan untuk menolong sesama manusia. Kegiatan ini meliputi Mencari, menolong, dan menyelamatkan jiwa manusia yang hilang atau dikhawatirkan hilang atau menghadapi bahaya dalam bencana atau musibah. Karakter yang terbentuk dalam kegiatan ini adalah:

a) Kerja Keras

b) Disiplin

\section{2) Marching Band}

Marching Band dilaksanakan dengan membuat program kerja mingguan, tahunan dan program kerja insidental. Program kerja mingguan mencakup kegiatan rutin yang dilakukan selama satu minggu yaitu latihan rutin, pengkondisian peralatan apabila hendak latihan dan evaluasi sesudah latihan. Karakter yang terbentuk dalam kegiatan ini yaitu:

a) Percaya Diri

b) Kerjasama

c) Kepemimpinan

\section{3) Kegiatan Halang Rintang}

Kegiatan halang rintang lebih menekankan pada aspek fisik dengan melintasi berbagai permainan dan rintangan sehingga mahasiswa diharuskan untuk melakukan pemanasan supaya tidak terjadi kecelakaan. Adapun karakter yang terbentuk dalam kegiatan ini yaitu:

a) Kerja Keras

b) Disiplin

\section{4) Kegiatan Silaturrahmi}

Kegiatan silaturrahmi juga dibiasakan pada semua anggota Unit Kegiatan Mahasiswa UKM. Kegiatan ini dilakukan antara Pengurus dan anggota supaya tidak ada jarak dalam berinteraksi seperti yang dikatakan oleh Wakil Komandan Satuan dibawah ini:

"manusia itu ibarat satu tubuh, jika satu sakit maka semua harus merasa sakit, jika satu terluka maka semua harus merasa terluka. Itulah yang ditanamkan kepada calon anggota sehingga jika satu anggota sakit semua anggota lain harus mengetahuinya.

Pada pernyataan di atas dapat dipahami bahwa kegiatan silaturrahmi sudah ditanamkan sejak awal yaitu ketika masih menjadi calon anggota sampai kegiatan 


\section{Pembentukan Karakter; Studi Unit Kegiatan Mahasiswa UIN Sunan Kalijaga Yogyakarta} Muhammad Roihan Alhaddad

ini menjadi pembiasaan bagi anggotanya. Kegiatan ini sangat penting untuk mengakrabkan diri satu sama lain.

\section{Strategi Pembentukan Karakter UKM LPM Arena}

a. Strategi Knowing the Good

1) Pengembangan Wacana

Pada Unit Kegiatan Mahasiswa Arena, untuk anggota yang masuk pada UKM ini diwajibkan untuk membaca buku tentang jurnalistik supaya bisa memahami bagaimana menulis yang baik, menarik pembaca, dan mempengaruhi pembaca. Buku yang memang dianjurkan dibaca yaitu buku tentang Sembilan Elemen Jurnalis untuk menjadi pengetahuan awal bagi para anggota baru. Karakter yang terbentuk dalam kegiatan ini yaitu:

a) Rasa Ingin Tahu

b) Gemar Membaca

\section{2) Pelatihan Jurnalistik}

Masyarakat yang disebut Citizen Journalism itu menandai revolusi penyebaran informasi. Dengan internet dan perantaraan blog, semua orang bisa menjadi wartawan. Demikian halnya perkembangan jurnalisme yang sedang berkembang cepat menuntut berbagai perubahan dalam kompetensi mahasiswa, namun mahasiswa Arena handal harus bekerja berdasarkan kompetensi sehingga menjadi profesional. Adapun karakter yang terbentuk dalam kegiatan ini yaitu:

a) Kreatif

b) Rasa Ingin Tahu

\section{3) Kajian Sastra}

Para mahasiswa juga harus memiliki pengetahuan, bagaimana cara menghargai hasil-hasil karya sastra terutama hasil karya sastra bangsa Indonesia sendiri. Dalam hal ini, peranan Pengurus pun sangat penting karena mereka harus dapat mengarahkan dan membimbing para mahasiswa dalam mempelajari karyakarya sastra tersebut. Kegiatan ini telah membentuk karakter mahasiswa yaitu:

a) Kerja Keras

b) Gemar Membaca

\section{4) Diskusi Ilmiah}

UKM Arena mengadakan diskusi rutin setiap hari Selasa dengan tema Filsafat dan hari jum'at dengan tema Kepenulisan. Dengan diskusi ini diharapkan mahasiswa mempunyai pola pikir atau idealisme dalam menulis sebuah berita yang mendasarinya sehingga berita yang ditulis sangat menarik perhatian pembaca. Kegiatan diskusi ini membentuk mahasiswa mempunyai karakter yaitu:
a) Komunikatif
b) Rasa Ingin Tahu 
Volume 2 Nomor 1 Edisi Juni 2017

P-ISSN : 2541-3686

\section{b. Strategi Action the Good}

1) Latihan Rutin Kepenulisan

Latihan rutin kepenulisan dilakukan oleh Unit Kegiatan Mahasiswa Arena untuk mengajak anggota untuk menulis artikel setiap bulan untuk dikoreksi oleh Pengurus sehingga jika ada kekurangan dalam hal tulisan maka akan dibimbing untuk menulis lebih baik lagi. Hasil dari tulisan anggota yang dianggap bagus oleh Pengurus akan diterbitkan di website resmi Arena maupun dicetak di buletin setiap bulannya. Karakter yang terbentuk dalam kegiatan ini yaitu:

a) Kerja Keras

b) Menghargai Prestasi

\section{2) Menerbitkan Majalah, Bulletin Slilit dan Portal}

Kegiatan ini menjadi salah satu wadah bagi mahasiswa untuk menumbuhkan kreatifitas mahasiswa dalam kegiatan kepenulisan yang diterbitkan di majalah, buletin maupun di portal Unit Kegiatan Mahasiswa Arena di lpmarena.com. adapun karakter yang terbentuk dalam kegiatan ini yaitu:
a) Kreatif
b) Mandiri
c) Disiplin

\section{Efektifitas Pembentukan Karakter UKM}

\section{Efektifitas Pembentukan Karakter UKM Al-Mizan}

a. Pendidikan dan Latihan

Menurut Haidar Ali (ketua UKM JQH Al-Mizan), bahwa kegiatan ini efektif dalam membentuk karakter kerja keras, dan disiplin mahasiswa dengan melihat banyaknya mahasiswa yang ingin mengikuti Unit Kegiatan Mahasiswa JQH AlMizan dengan jumlah 500-an walaupun yang diterima hanya 160-an mahasiswa.

\section{b. Kegiatan Workshop}

Kegiatan workshop sudah efektif membentuk karakter kerja keras dan disiplin dengan mengacu kepada tujuan kegiatan dan hasil (output) yang dicapai.

\section{c. Bedah Tafsir dan Kajian Kontemporer}

Penulis telah melihat bagaimana perkembangan intelektual mahasiswa dalam mengikuti bedah tafsir dan kajian kontemporer tersebut sehingga kegiatan ini sudah efektif membentuk karakter mahasiswa yang religius, berpikir logis, dan gemar membaca.

\section{d. Wisata Seni}

Kegiatan wisata seni sudah efektif dalam membentuk karakter rasa ingin tahu, dan kreatif dalam diri mahasiswa khususnya anggota divisi Tilawah.

\section{e. Latihan Rutin}

pelaksanaan kegiatan latihan rutin sudah efektif dalam membentuk karakter disiplin, kerja keras, kreatif, percaya diri, rasa ingin tahu, tanggungjawab, menghargai prestasi, dan gemar membaca mahasiswa dengan melihat proses 
kegiatannya dan penerimaan masyarakat terhadap mahasiswa yang terlibat di Unit Kegiatan Mahasiswa JQH Al-Mizan.

\section{f. Sima'an dan setoran hafalan}

Kegiatan sima' an dan setoran hafalan sudah efektif dalam membentuk karakter religius, kerja keras, dan disiplin mahasiswa dalam menghafal Al-Qur'an. Kegiatan ini efektif dengan mengacu kepada produktivitas dan kualitas dari kegiatan ini.

\section{g. Silaturrahmi dan Keakraban}

Kegiatan yang merupakan program Pengurus Harian tiga kali dalam satu kepengurusan ini pelaksanaannya sudah efektif dengan melihat cara komunikasi sesama Pengurus maupun anggota yang sangat akrab yang sering penulis lihat dalam setiap acara maupun hanya kumpul bersama di Student Center (SC).

\section{h. Mizanuna Berkreasi}

Kegiatan ini sudah efektif karena tujuan yang ingin dicapai oleh Pengurus Harian telah tercapai salah satunya dengan melibatkan anggota untuk berkreasi di acara puncak tersebut.

\section{i. Haflah Tilawah}

Menurut penulis, pelaksanaan kegiatan ini efektif dilakukan dengan tercapainya tujuan yang diinginkan dari program kegiatan haflah ini.

\section{j. Wisuda Hafidz dan Hafidzah}

Kegiatan wisuda hafidz dan hafidzah ini merupakan wadah yang sangat bagus untuk membuat mahasiswa menyempatkan waktu untuk menghafal Alqur'an secara rutin. kegiatan ini efektif dalam membentuk karakter mahasiswa khususnya anggota dari Unit Kegiatan Mahasiswa JQH Al-Mizan.

\section{k. Lomba Kaligrafi}

Kegiatan ini efektif dalam membentuk karakter menghargai prestasi, dan tanggungjawab mahasiswa. Karakter tersebut telah dibuktikan dengan kelancaran kegiatan lomba tersebut dengan baik.

\section{Efektifitas Pembentukan Karakter UKM Mapalaska \\ a. Ekspedisi Karimun Jawa}

Kegiatan ini dilaksanakan secara efektif dalam membentuk karakter peduli lingkungan, dan rasa ingin tahu mahasiswa oleh Pengurus Mapalaska dengan melihat proses pelaksanaan yang dikaitkan dengan tujuan kegiatan tersebut.

\section{b. Diskusi Ilmiah Lingkungan Hidup}

Kegiatan ini berjalan dengan efektif dalam membentuk karakter rasa ingin tahu, gemar membaca, dan komunikatif dalam diri mahasiswa. Kegiatan ini efektif dengan melihat tujuan dan hasil yang telah dicapai oleh Pengurus Mapalaska.

\section{c. Pendidikan Lanjut}

kegiatan ini efektif dalam membentuk karakter disiplin, kerja keras dan tanggungjawab mahasiswa. Kegiatan ini juga efektif dengan menarik peminat untuk ikut serta dalam Unit Kegiatan Mahasiswa Mapalaska. 


\section{d. Bakti Sosial}

Kegiatan ini sudah efektif dalam membentuk karakter peduli sosial, dan ketulusan mahasiswa yang membantu masyarakat tanpa pamrih.

\section{e. Pendakian Kemerdekaan}

Kegiatan ini efektif dalam membentuk karakter cinta tanah air, dan pantang menyerah mahasiswa. Kegiatan ini juga efektif dengan mengacu kepada tujuan tersebut.

\section{f. Pengabdian pada Masyarakat Ramadhan}

Kegiatan pengabdian pada masyarakat yang dilaksanakan pada bulan ramadhan di tahun 2013 efektif dalam membentuk karakter peduli sosial, tanggungjawab, dan ketulusan mahasiswa.

\section{g. Silaturrahmi Antar Anggota}

Kegiatan ini efektif untuk menjaga keakraban sesama anggota Mapalaska yang masih aktif maupun yang sudah alumni dengan merencanakan kegiatan pendakian bersama Mapalaska Se-Indonesia.

\section{h. Kegiatan Yasinan Anggota}

Kegiatan yasinan yang direncanakan oleh Pengurus Mapalaska satu bulan sekali kurang efektif untuk mencapai tujuan yang ingin membentuk mahasiswa yang agamis. Kualitas dari kegiatan yasinan ini hanya dihadiri oleh sedikit mahasiswa dan juga tidak menghasilkan hasil yang maksimal.

\section{Efektifitas Pembentukan Karakter UKM Olahraga \\ a. Pengadaan Pelatih}

Dari hasil wawancara dan observasi yang penulis lakukan bahwa program kegiatan pengadaan pelatih yang dilakukan oleh divisi Sepakbola, Futsal, dan Bulutangkis efektif dalam membentuk karakter rasa ingin tahu, dan disiplin mahasiswa.

\section{b. Latihan Rutin}

Kegiatan rutin sangat dibutuhkan oleh setiap Unit Kegiatan Mahasiswa dengan tujuan yang hampir sama. Kegiatan ini sudah efektif dalam membentuk karakter kerja keras, dan disiplin mahasiswa dalam bermain.

\section{c. Sparing Partner}

Kegiatan ini sudah efektif dalam membentuk karakter kerja keras, disiplin, tanggungjawab, dan percaya diri mahasiswa. Kegiatan juga efektif dengan mengacu kepada hasil dari tujuan kegiatan yang dilaksanakan oleh setiap divisi Unit Kegiatan Mahasiswa Olahraga.

\section{d. Mengikuti event}

Kegiatan ini dilaksanakan secara efektif oleh Unit Kegiatan Mahasiswa Olahraga dalam membentuk karakter kerja keras, disiplin, kerjasama, dan percaya diri mahasiswa. 


\section{e. Mengadakan Turnamen}

kegiatan ini efektif dalam membentuk karakter tanggungjawab mahasiswa. Kegiatan ini juga efektif mengacu kepada tujuan kegiatan dengan menghasilkan atlet-atlet baru yang berbakat.

\section{Efektifitas Pembentukan Karakter UKM Resimen Mahasiswa \\ a. Pendidikan dan Latihan}

Kegiatan ini dilaksanakan secara efektif oleh Pengurus sesuai dengan rencana awal yang telah disepakati. Pendikan dan latihan ini telah membentuk mahasiswa mempunyai sikap disiplin, kerja keras dan tanggungjawab.

\section{b. Bakti Sosial}

Kegiatan sosial seperti ini sudah efektif untuk menumbuhkan sikap kepedulian sosial, tanggungjawab dengan terjun langsung untuk membantu masyarakat yang membutuhkan.

\section{c. Upacara Hari Kemerdekaan RI}

Hal yang paling mudah dilakukan adalah mengikuti upacara hari kemerdekaan Indonesia merupakan pondasi awal untuk menumbuhkan sikap nasionalisme. Kegiatan ini efektif dilaksanakan oleh Pengurus MENWA dalam membentuk mahasiswa yang berjiwa nasionasilme.

\section{d. Latihan Search and Rescue}

Kegiatan ini efektif dilaksanakan guna membentuk karakter disiplin dan kerja keras mahasiswa. Kegiatan ini juga efektif dengan mengacu kepada tujuan, dan hasilnya.

\section{e. Marching Band}

Kegiatan ini efektif dalam menumbuhkan sikap kerjasama, kepemimpinan mahasiswa yang mampu diintegrasikan dalam kehidupan sehari-hari.

\section{f. Kegiatan Halang Rintang}

Kegiatan ini efektif dalam membentuk karakter kerja keras, dan disiplin mahasiswa. Karakter itu dibuktikan mahasiswa dengan mampu melewati rintangan yang telah dibuat.

\section{g. Kegiatan Silaturrahmi}

Silaturrahmi pada dasarnya bertujuan baik untuk tetap menjaga hubungan persaudaraan. Siapapun dianjurkan melakukannya pada agama apapun. Kegiatan ini efektif untuk menumbuhkan sikap kasih sayang, tulus, dan keakraban antar mahasiswa.

\section{Efektifitas Pembentukan Karakter UKM Arena \\ a. Pengembangan Wacana}

Kegiatan ini efektif untuk membuka pengetahuan dasar tentang kepenulisan dan membentuk mahasiswa mempunyai sikap rasa ingin tahu dan gemar membaca. 
Volume 2 Nomor 1 Edisi Juni 2017

P-ISSN : 2541-3686

\section{b. Pelatihan Jurnalistik}

Kegiatan ini efektif dalam membentuk karakter kreatif, dan rasa ingin tahu mahasiswa. Kegiatan ini juga efektif dengan melihat hasil dari kegiatan dan antusias mahasiswa yang mengikuti pelatihan tersebut.

\section{c. Kajian Sastra}

Kegiatan ini kurang efektif dengan alasan bahwa kegiatan ini tidak dilakukan secara konsisten dan tepat waktu sesuai dengan yang diagendakan.

\section{d. Diskusi Ilmiah}

Kegiatan diskusi ini telah menumbuhkan sikap rasa ingin tahu, gemar membaca, dan komunikatif dalam diri mahasiswa Unit Kegiatan Mahasiswa Arena.

\section{e. Menerbitkan Majalah, Bulletin Slilit dan portal}

Dalam pelaksanaannya kegiatan ini sudah efektif dalam membentuk karakter kreatif, mandiri, dan disiplin mahasiswa yang dibuktikan dengan menghasilkan buletin tersebut.

\section{Faktor Pendukung dan Penghambat dalam Pembentukan Karakter}

1. Faktor Pendukung dalam Pembentukan Karakter

\section{a. Strenght (kekuatan)}

1) Orang yang terlibat dalam pembentukan karakter baik itu Pengurus maupun anggota sudah mempunyai ilmu pengetahuan karena sudah menjadi mahasiswa sehingga tidak terlalu sulit untuk mengajarkan, dan mengarahkannya.

2) Lingkungan yang kondusif telah disediakan oleh Universitas UIN Sunan Kalijaga Yogyakarta untuk mendukung untuk mendukung kegiatan Intra Kampus yang terletak di Student Center.

3) Kegiatan-kegiatan yang telah dirancang di awal kepengurusan yang sangat baik. Dengan kegiatan-kegiatan tersebut mahasiswa diarahkan dan dibiasakan untuk menjadi mahasiswa yang berkarakter.

4) Kemauan dan kesadaran mahasiswa dalam mengikuti kegiatan yang dibuat oleh Pengurus merupakan faktor penting. Tanpa adanya kemauan dan kesadaran mahasiswa sudah pasti tujuan yang tak akan tercapai.

b. Opportunity (peluang).

1) Mahasiswa akan mempunyai karakter yang tangguh dalam kehidupan bermasyarakat.

2) mudah diterima di dalam masyarakat dengan karakter dan kemampuan yang mahasiswa dapatkan dalam mengikuti kegiatan-kegiatan UKM tersebut.

3) Mendapatkan prestasi lewat turnamen atau event yang ada di Yogyakarta maupun tingkat nasional.

2. Faktor Penghambat dalam Pembentukan Karakter

\section{a. Weakness (kelemahan)}




\section{Pembentukan Karakter; Studi Unit Kegiatan Mahasiswa UIN Sunan Kalijaga Yogyakarta Muhammad Roihan Alhaddad}

1) Dalam melaksanakan suatu kegiatan masih banyak mahasiswa yang tidak ikut serta karena alasan akademik seperti, mengerjakan tugas, kuliah dan sebagainya sehingga menyulitkan Pengurus dalam merangkul mereka dalam setiap kegiatan.

2) Anggota yang sudah terdaftar di Unit Kegiatan Mahasiswa terkadang merasa malu untuk mengikuti kegiatan karena selama ini mereka tidak pernah ikut kegiatan sebelumnya.

3) Kurangnya dana dalam melaksanakan program sehingga membuat mereka mencari dana ataupun meminimalisir dana kegiatan, contohnya UKM arena yang harus menerbitkan buletin setiap bulannya.

4) Fasilitas lapangan untuk latihan yang masih kurang seperti belum adanya lapangan untuk olahraga bulutangkis dan sepakbola.

b. Threath (ancaman).

1) Lingkungan kost mahasiswa yang kurang baik akan mempengaruhi karakter mahasiswa kedepannya.

2) Kepentingan-kepentingan individu maupun kelompok dalam berorganisasi akan merusak iklim organisasi itu sendiri.

3) Pergaulan yang bebas juga merupakan salah satu ancaman yang akan dihadapi mahasiswa di masa yang akan datang.

4) Kegiatan-kegiatan yang berkurang karena mahasiswa sudah mempunyai jadwal yang padat sehingga akan berpengaruh terhadap porsi kegiatan yang dilakukan dalam membentuk karakter.

\section{Simpulan}

Strategi Pembentukan Karakter di Unit Kegiatan Mahasiswa UIN Sunan Kalijaga menggunakan strategi knowing the good, strategi loving and feeling the good, strategi action the good, Strategi keteladan, dan taubat.

Efektifitas Pembentukan Karakter di Unit Kegiatan Mahasiswa UIN Sunan Kalijaga dengan melihat dari sisi pelaksanaan program, waktu, kualitas, efisiensi, dan hasilnya sejauh ini dapat dikatakan efektif dalam membentuk karakter mahasiswa. Setelah mengikuti kegiatan-kegiatan yang dilaksanakan secara terusmenerus oleh Pengurus Unit Kegiatan Mahasiswa yang dijelaskan di rumusan masalah pertama sehingga setelah mengikuti kegiatan-kegiatan tersebut mahasiswa mempunyai karakter religius, disiplin, kerja keras, kreatif, mandiri, rasa ingin tahu, cinta tanah air, menghargai prestasi, komunikatif, gemar membaca, peduli lingkungan, peduli sosial, tanggungjawab, dan ketulusan telah efektif dibentuk oleh Pengurus terhadap anggotanya.

Adapun faktor pendukung dan penghambat dalam Pembentukan Karakter di Unit Kegiatan Mahasiswa UIN Sunan Kalijaga telah dianalisis menggunakan analisis SWOT yaitu strength (kekuatan), weakness (kelemahan), opportunity (peluang), dan threath (ancaman). Penulis telah menemukan beberapa faktor pendukung dan penghambat dalam pembentukan karakter tapi semua itu tidak menjadi halangan yang berarti bagi Pengurus untuk tetap menjadikan mahasiswa berkarakter baik. 
RAUDHAH Proud To Be Professionals qurnal Tarbiyakndamiyah

Volume 2 Nomor 1 Edisi Juni 2017

P-ISSN : 2541-3686

\section{DAFTAR PUSTAKA}

Arifin, Zainal, Penelitian Pendidikan Metode dan Paradigma Baru, Bandung: Remaja Rosdakarya, 2011.

Asmani, Jamal Ma'mur, Buku Panduan Internalisasi Pendidikan Karakter di Sekolah, Yogyakarta: diva Press, 2012.

Hidayat, Efektifitas Pencapaian hasil Berorganisasi, Bandung: Media Karya, 1986.

Koesuma A, Doni, Pendidikan Karakter, strategi Mendidik Anak di Zaman Global, Jakarta: Grasindo, 2010.

Lickona, Thomas, Pendidikan Karakter: Panduan Lengkap Mendidik Siswa Menjadi Pintar dan Baik Terj. Educating For Character. Bandung: Nusa Media, 2013.

Moleong, Lexy, Metodologi Penelitian Kualitatif, Bandung: Remaja Rosdakarya, 2008.

Sarjono, dkk. Panduan Penulisan Skripsi Jurusan Pendidikan Agama Islam, Yogyakarta: Jurusan Pendidikan Agama Islam, Fakultas Tarbiyah UIN Sunan Kalijaga, 2008.

Siregar, Maragustam, Mencetak Pembelajar Menjadi Insan Paripurna, Yogyakarta: Nuha Litera, 2010.

Tim Bahasa Pustaka Agung Harapan, Kamus Cerdas Bahasa Indonesia Terbaru, Surabaya: CV Pustaka Agung Harapan, 2003.

Tim Prima Pena, Kamus Ilmiah Populer Edisi Lengkap Referensi Ilmiah Ideologi, Politik, Hukum, Ekonomi, Sosial, Budaya, dan Sains, Surabaya: Gitamedia Press, 2006.

Megawangi, Ratna, Membangun SDM Indonesia Melalui Pendidikan Holistik Berbasis Karakter, melalui website www.usm.maine.com diakses 24 November 2013.

Mudjia Rahardjo, Triangulasi dalam Penelitian Kualitatif, melelui website http://mudjiarahardjo.com, diakses 29 Oktober 2013. 
Pembentukan Karakter; Studi Unit Kegiatan Mahasiswa UIN Sunan Kalijaga Yogyakarta Muhammad Roihan Alhaddad 